\title{
逐次確率比検定法による労働災害発生率の統計評価に関する研究

\author{
STATISTICAL EVALUATION FOR ACCIDENT FREQUENCY RATES BY \\ SEQUENTIAL PROBABILITY RATIO TESTS
}

\author{
花 安繁 郎*・五十嵐日出夫** \\ By Shigeo HANAYASU and Hideo IGARASHI
}

\begin{abstract}
Testing hypotheses for the accident frequency rates in construction works were applied to discover the significant changes in the accident situation in succeeding intervals of time. The time intervals between occupational accidents were employed as a useful indicator to measure the safety performance in construction sites. In order to save the sample number of accidents as well as the time periods to reach a statistical decision, sequential probability ratio tests were utilized for testing hypotheses of accident frequency rates. By making use of the sequential tests for various types of accidents, some features of accident situation were identified. Diagrams illustrating a sequential testing procedure could also be used as a control chart in safety management.
\end{abstract}

Keywords: occupational accidents, construction work, statistical analysis, testing hypotheses, accident frequency rate

\section{1. まえがき}

事業所において労働災害の発生危険性を評価する指標 には, 単位労働時間あるいは単位労働力当たりの災害発 生件数で示される災害発生頻度率が広く用いられてい る. 特に, 単位労働時間数が 100 万時間のときの頻度率 はわが国では災害度数率とよばれており, 労働省による 労働災害動向調査によって産業別・業種別などに分類さ れた全国平均の観測値が毎年報告されている1).

著者はこれまで，この度数率に代表される労働災害発 生頻度率が, 建設工事作業場等において, 工事の進行に 応じて変動する過程を, 労働災害が発生するまでの時間 数を用いて評価する方法について考察を加えてきた.

これまでに行ったさまざまな調査・分析から得られた 結果には, たとえば, 最近の建設工事における労働災害 の多くがほぼランダムに発生していること, すなわち, 労働災害が発生するまでの時間数の確率分布式が指数分 布やガンマ分布で表現されること, また, これらの分布 式のパラメーターが災害度数率と関連づけられることな

* 正会員 工博 労働省産業安全研究所 土木建築研究部 （宁108 港区芝 5-35-1）

** 正会員 工博 北海道大学教授 工学部土木工学科 ( ₹060 札幌市北区北 13 条西 8 丁目)
ビが挙げられる2) 6).

これらの知見により, 労働災害発生率の変動を調べる ことは, 災害発生時間数の確率分布式の母数の変動を調 べることと同等であり，統計学的には指数分布あるいは ガンマ分布の母数 (=災害発生率) に対する統計的仮説 検定を行うことに帰着することが示される.

ところで, 実際に得られた災害デー夕を用いて災害発 生率の仮説検定などの統計的推測を行うにあたっては, 限られた標本を通して母集団特性值を調へようとするの であるから, そこで得られる結論には, データの変動や 誤差などに起因する統計的な判断の誤り（統計的過誤） が必ず含まれることになる.

周知のように, 統計的仮説検定時に生ずる判断の誤り （統計的過誤）には，i）帰無仮説が真であるにもかか わらずこれを棄却してしまう誤り（第 1 種の過誤）と, ii）対立仮説が正しいにもかかわらずこれを棄却してし まう誤り（第 2 種の過誤）との 2 種類がある.このうち 災害発生率の仮説検定で安全上特に問題になるのは, 実 際の災害発生率が帰無仮説で設定された值より大きいに もかかわらず州無仮説を採択してしまう場合なので, 第 2 種の過誤の取扱いは大変重要となってくる. そしてこ の第 2 種の過誤を少なくするためには, ある特定件数以 上の標本 (災害データ) を用いて仮説検定を行うことが 
必要である。

ところが，労働災害はそう頻繁に起こるわけではない ので，過誤として設定された危険水準を充足する数の災 害デー夕が常に得られるとは限らない. また現実にはそ の場で得られたありあわせのデータを用いて評価を実施 したり，あるいはせざるを得ないことが多い.

そこで本研究では，通常の仮説検定と同等の危険水準 を保証した検定法であり，かつ評価に要する災害件数が 少なく，また評価時間数も短く済ませることができる逐 次確率比検定法（通常は逐次検定法と略称される）をと りあげ，同検定方式を用いて災害発生率の変動を評価す る手順等について考察を加えるとともに, 実際に発生し た災害データを用いて災害動向の変動について分析を試 みた. 本稿はそれらの結果をまとめたものである.

\section{2. 労働災害発生時間数による統計的評価}

本章では，逐次検定を検討する前の準備として，通常 の統計的仮説検定について述べる.まず，労働災害発生 時間数の分布について，特に分布のパラメーターと災害 度数率との関連を述べたのち，労働災害発生時間数を用 いて災害発生率の仮説検定を行う手順について触れ，さ らに，検定に要する平均評価災害件数や時間数などの仮 説検定の評価関数について考察を加えた。

（1）度数率をパラメーターとした発生時間分布式

まず，災害発生時間数の確率分布式については，これ までのいくつかの災害事例の調査から, 個々の災害の発 生時間 (間隔) 分布は指数分布に，また複数件の災害が 発生するまでの時間分布はガンマ分布に従うことが知ら れている ${ }^{3), 5)}$. 指数分布の確率密度関数を以下に示す.

$$
\left.\begin{array}{l}
f_{1}(t)=\lambda \exp \{-\lambda t\} \\
E_{1}(T)=1 / \lambda, \quad V_{1}(T)=1 / \lambda^{2}
\end{array}\right\}
$$

これらの分布式は，単位時間当たりの発生頻度率 $\lambda$ をパラメーターとする分布式であるが, このパラメー タ一值は, $T$ 時間で $K$ 件の労働災害が発生したとする と, 最尤法によって $\lambda=K / T$ がその推定值として得ら れる4!

一方，災害度数率（以下 $A$ と略記）とは 100 万労働 時間当たりの災害発生数と定義されている.したがって, 上式の指数分布，あるいはガンマ分布のパラメーター と度数率 $A$ とは, 次式のごとく関係づけることができ る.

$$
\lambda=A / 100
$$

ただし， $A$ : 災害度数率 (単位：1／万時間)

かくして，産業別なり，業種別なり，あるいは工事別 なりでの，ある度数率 $A_{0}$ が与えられれば， $A_{0}$ のもとで の災害発生時間数の確率分布を規定することができるの で，その分布と災害発生時間数とのデータとを用いて，
度数率 $A_{0}$ の変動を統計的仮説検定法によって評価する ことができる.

\section{（2）烦害発生率の統計的仮説検定の手順}

労働災害発生時間数を用いて災害度数率の変動を統計 的に評価するための統計的仮説検定の手順はおおよそ以 下のようにまとめられる ${ }^{6), 7)}$.

1）母集団に関する基本仮定を立てる．ここでは，災 害発生時間分布は指数分布あるいはガンマ分布であると 仮定している.

2）帰無仮説 $H_{0}$ および対立仮説 $H_{1}$ を立てる. 仮説 の立て方には, まず, 変動が予想されるもとの度数率を 用いて帰無仮説 $H_{0}$ を設定し，

\section{$H_{0}: A=A_{0}\left(A_{0}:\right.$ もとの度数率 $)$}

ついで，帰無仮説が棄却されたときに採択される対立仮 説を定める. 対立仮説の設定の仕方には，“度数率は大 きくなっていないか？”を検定する，

$$
H_{1}: A=A_{1}>A_{0}
$$

あるいは, “度数率は小さくなっているか？”を考える，

$$
H_{1}: A=A_{1}<A_{0}
$$

などの，標本統計量分布の左側，あるいは右側のみに有 意水準に対応した棄却域を設ける片側検定方式のほか, “度数率には変化がないか？”を検定する，

$$
H_{1}: A=A_{1} \neq A_{0}
$$

で示される，両側検定方式による仮説設定法がある.

3）第 1 種過誤 (有意水準) $\alpha$ および第 2 種過誤 $\beta$ を 設定する.

4）検定に用いる統計量（検定基準）を選択する.こ こでは災害発生時間数を検定量として用いている。

5）帰無仮説 $H_{0}$ および対立仮説 $H_{1}$ のもとでの検定 基準の分布を求め, $H_{0}$ のもとでの分布領域を棄却域と 採択域に分ける.

6）所定の有意水準 $\alpha$ と第 2 種の過誤 $\beta$ を満たすサ ンプルの大きさを決定する

たとえば, $H_{0}: A=A_{0}$ に対して $H_{1}: A=A_{1}>A_{0}$ の検 定において，統計的過誤が有意水準 $\alpha$ とともに第 2 種 過誤の確率 $\beta$ 以下であるためには，次式を満足せねば ならず

$$
\frac{\lambda_{1}}{\lambda_{0}}=\frac{A_{1}}{A_{0}} \geqq \frac{\chi^{2}(\phi: \beta)}{\chi^{2}(\phi: 1-\alpha)}
$$

ただし $\chi^{2}(\phi: \varepsilon): \chi^{2}$ 分布上側確率值が $\varepsilon$ となる $\chi^{2}$ 値 同式を満足する最小の正数を $K_{0}$ とおくと，このときの 自由度は $\phi_{0}=2 K_{0}$ となり，棄却域が次式で与えられる.

$$
t \leqq \frac{\chi^{2}\left(2 K_{0}: 1-\alpha\right)}{2 \lambda_{0}}=\frac{50 \cdot \chi^{2}\left(2 K_{0}: 1-\alpha\right)}{A_{0}}
$$

表一1には， $\alpha$ および $\beta$ をともに $0.01 \sim 0.20$ の間で 5 段階に変化させ，また，1.50〜 10.0 の間で 8 段階の 判別比 $\left(D=A_{1} / A_{0}\right)$ を設定したときの, 式（3）を満 
足する最小正数 $K_{0}$ を求めた結果を示した. 同表より， たとえば $D=A_{1} / A_{0}=2.0$ の検定を行うとき， $\alpha$ および $\beta$ の危険率をともに 0.05 以下にしたければ，少なくと も災害件数が 23 件目以上での発生時間数を用いて検定 しなければならないことや，判別比が大きいほど $K_{0}$ が 少なくて済むことなどがわかる，同様に表一2には， $H_{0}$ $: A=A_{0}$ に対して $H_{1}: A=A_{1}<A_{0}$ を検定するときの, $K_{0}$ を求めた結果を示した.

7）対象とする集団からサンプルをとって検定基準統 計量を求め, これが棄却域に落ちる場合は有意水準 $\alpha$ で $H_{0}$ を棄却する. もしサンプル数が表に示された数以 上であれば，第 2 種過誤の確率は所定の值 $\beta$ 以下とな る.

図一 1 には, $A_{1}>A_{0}$ の検定の場合で， $\alpha=\beta=0.10$ を 満足する最小災害件数 $\left(K_{0}\right)$ と，それに対応した棄却 域をいくつかの判別比 $\left(D=A_{1} / A_{0}\right)$ について求めた結 果を示した。同図より, たとえば， $H_{0}: A_{0}=5.0, H_{1}$ : $A_{1}=10.0$, 判別比 $D=2.0$ の検定を行うには, $K_{0}=15$ 件目の災害発生時間数を調へ，これが 206 万時間以下で あれば帰無仮説を棄却すればよい．このときの有意水準 は 0.10 ，第 2 種の過誤は 0.10 以下であることが保証さ れる.

同様に，図一2には， $A_{1}<A_{0}$ の仮説検定で $\alpha=\beta=$ 0.10 のときの, 最小災害件数 $\left(K_{0}\right)$ 之, 棄却域をいく
つかの判別比について計算した結果を示した. 同図より, たとえば, $H_{0}: A_{0}=5.0, H_{1}: A_{1}=2.50$, 判別比 $D=$ $1 / 2$ の検定を行うには, $K_{0}=15$ 件目の災害発生時間数 が 403 万時間以上であれば帰無仮説を棄却する。このと きの統計的判断の誤りの確率は上述の值が保証される.

\section{(3) 平均評価時間数および平均評価災害件数}

いまある検定方式のもとで，帰無仮説および対立仮説 の值（したがって判別比），有意水準 $\alpha$, 第 2 種過誤 $\beta$ などを定めると，これらの設定值に対応して表一1，2 なよ゙より設定基準を充足する最小災害件数 $K_{0}$ が求ま り，またこの $K_{0}$ 件目災害発生時間の棄却域が式（4） などによって求めることができる。この棄却域となる時 間数をここでは $T_{c}$ と書き，さらに，事業所などで実際 に発生した $K_{0}$ 番目災害の発生時間数を $X_{0}$ と書くこと にする。

すると，対立仮説が $A>A_{0}$ の場合の検定では， $X_{0} \leqq T_{c}$ のときに帰無仮説を裹却し， $X_{0}>T_{c}$ では帰無仮 説を採択することとなり，同様に，対立仮説が $A<A$ 。 の検定では， $X_{0} \geqq T_{c}$ のときに帰無仮説を棄却し，また $X_{0}<T_{c}$ のときは帰無仮説を採択することとなる。

この方式での評価のために必要な災害件数は前述の最 小必要災害件数 $K_{0}$ であり，また判断に至る平均的な評 価時間は $K_{0}$ 件の災害が発生するまでの平均時間数なの で，度数率を $A$ として次式で得られる。

表一1 検定条件を充足する最小绅害件数 $K_{0}$ （片側検定 $A_{1}>A_{0}$ ）

\begin{tabular}{|c|c|c|c|c|c|c|c|c|c|c|c|c|c|c|c|c|c|c|c|c|c|c|c|c|c|}
\hline \multirow[b]{2}{*}{$\mathrm{A} / \mathrm{AB}$} & \multicolumn{5}{|c|}{$A L P H A=0.01$} & \multicolumn{5}{|c|}{$A L P H A=0.05$} & \multicolumn{5}{|c|}{ ALPHA $=0.10$} & \multicolumn{5}{|c|}{$A L P H A=0.15$} & \multicolumn{5}{|c|}{$A L P H A=0.20$} \\
\hline & .01 & 05. & 10. & 15. & 20 & .01. & 05. & 10. & 15. & 20 & .01 & 05. & 10. & 15. & 20 & 01. & 05. & 10. & 15 & 20 & .01 & 05 & 10 & .15 & .20 \\
\hline$D=1.50$ & 133 & 99 & 83 & 73 & 66 & 95 & 67 & 54 & 46 & 40 & 77 & 52 & 41 & 34 & 29 & 66 & 43 & 33 & 27 & 23 & 58 & 37 & 27 & 22 & 18 \\
\hline$D=2.00$ & 46 & 35 & 30 & 27 & 24 & 33 & 23 & 19 & 17 & 15 & 26 & 18 & 15 & 12 & 11 & 22 & 15 & 12 & 10 & 8 & 20 & 13 & 10 & 8 & 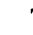 \\
\hline$D=2.50$ & 27 & 21 & 18 & 16 & 15 & 19 & 14 & 11 & 10 & 9 & 15 & 11 & 9 & 7 & 7 & 13 & 9 & 7 & 6 & 5 & 11 & 8 & 6 & 5 & \\
\hline$D=3.00$ & 19 & 15 & 13 & 12 & 11 & 13 & 10 & 8 & 7 & 7 & 11 & 8 & 6 & 5 & 5 & 9 & 6 & 5 & 4 & 4 & 8 & 5 & 4 & 4 & \\
\hline$D=4.00$ & 12 & 10 & 9 & 8 & 7 & 9 & 7 & 6 & 5 & 5 & 7 & 5 & 4 & 4 & 3 & 6 & 4 & 3 & 3 & 3 & 5 & 4 & 3 & 3 & 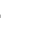 \\
\hline$D=5.00$ & 9 & 8 & 7 & 6 & 6 & 7 & 5 & 4 & 4 & 4 & 5 & 4 & 3 & 3 & 3 & 4 & 3 & 3 & 2 & 2 & 4 & 3 & 2 & 2 & \\
\hline$D=7.50$ & 6 & 5 & 5 & 4 & 4 & 4 & 4 & 3 & 3 & 3 & 4 & 3 & 2 & 2 & 2 & 3 & 2 & 2 & 2 & 2 & 3 & 2 & 2 & 2 & \\
\hline$D=10.00$ & 5 & 4 & 4 & 4 & 3 & 4 & 3 & 3 & 2 & 2 & 3 & 2 & 2 & 2 & 2 & 2 & 2 & 2 & 2 & 1 & 2 & 2 & 2 & 1 & 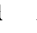 \\
\hline
\end{tabular}

表一2 検定条件を充足する最小災害件数 $K_{0}$ (片側検定 $\left.A_{1}<A_{0}\right)$

\begin{tabular}{|c|c|c|c|c|c|c|c|c|c|c|c|c|c|c|c|c|c|c|c|c|c|c|c|c|c|}
\hline $\begin{array}{l}\alpha \\
\beta\end{array}$ & \multicolumn{5}{|c|}{$A L P H A=0.01$} & \multicolumn{5}{|c|}{$A L P H A=0.05$} & \multicolumn{5}{|c|}{$A L P H A=0.10$} & \multicolumn{5}{|c|}{ ALPHA $=0.15$} & \multicolumn{5}{|c|}{$A L P H A=0.20$} \\
\hline $\mathrm{A} / \mathrm{AB}$ & .01 & 05 & 10. & 15 & 20 & .01 & 05. & 10 & 15 & 20 & .01 & 05 & 10 & 15. & 20 & .01 & 05 & 10 & 15 & 20 & .01 & 05. & 10 & 15 & 20 \\
\hline$D=0.67$ & 133 & 95 & 77 & 66 & 58 & 99 & 67 & 52 & 43 & 37 & 83 & 54 & 41 & 33 & 27 & 73 & 46 & 34 & 27 & 22 & 66 & 40 & 29 & 23 & 18 \\
\hline$D=0.50$ & 46 & 33 & 26 & 22 & 20 & 35 & 23 & 18 & 15 & 13 & 30 & 19 & 15 & 12 & 10 & 27 & 17 & 12 & 10 & 8 & 24 & 15 & 11 & 8 & 7 \\
\hline$D=0.40$ & 27 & 19 & 15 & 13 & 11 & 21 & 14 & 11 & 9 & 8 & 18 & 11 & 9 & 7 & 6 & 16 & 10 & 7 & 6 & 5 & 15 & 9 & 7 & 5 & 4 \\
\hline$D=0.33$ & 19 & 13 & 11 & 9 & 8 & 15 & 10 & 8 & 6 & 5 & 13 & 8 & 6 & 5 & 4 & 12 & 7 & 5 & 4 & 4 & 11 & 7 & 5 & 4 & 3 \\
\hline$D=0.25$ & 12 & 9 & 7 & 6 & 5 & 10 & 7 & 5 & 4 & 4 & 9 & 6 & 4 & 3 & 3 & 8 & 5 & 4 & 3 & 3 & 7 & 5 & 3 & 3 & 2 \\
\hline$D=0.20$ & 9 & 7 & 5 & 4 & 4 & 8 & 5 & 4 & 3 & 3 & 7 & 4 & 3 & 3 & 2 & 6 & 4 & 3 & 2 & 2 & 6 & 4 & 3 & 2 & 2 \\
\hline$D=0.13$ & 6 & 4 & 4 & 3 & 3 & 5 & 4 & 3 & 2 & 2 & 5 & 3 & 2 & 2 & 2 & 4 & 3 & 2 & 2 & 2 & 4 & 3 & 2 & 2 & 1 \\
\hline$D=0.10$ & 5 & 4 & 3 & 2 & 2 & 4 & 3 & 2 & 2 & 2 & 4 & 3 & 2 & 2 & 2 & 4 & 2 & 2 & 2 & 1 & 3 & 2 & 2 & 1 & 1 \\
\hline
\end{tabular}




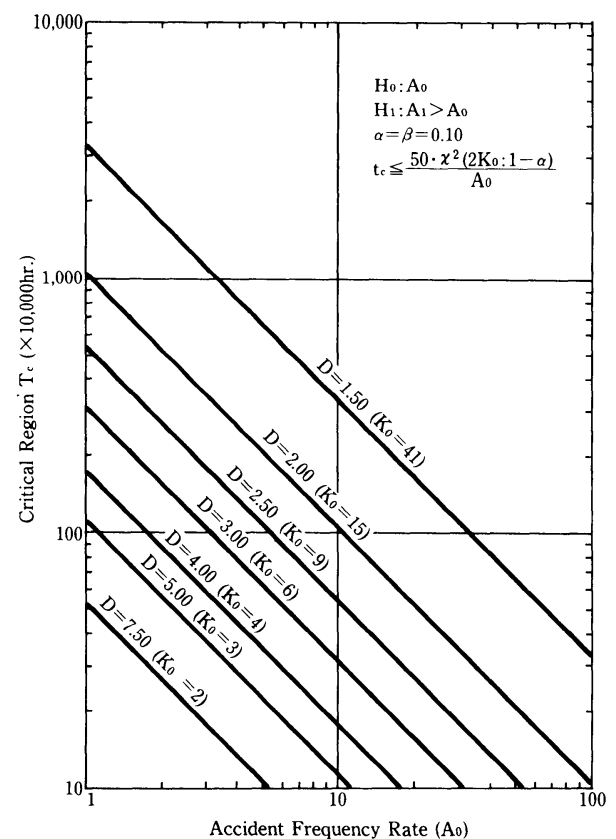

図-1 帰無仮説值 $A_{0}$ と衰却域 $T_{c}$ 関係 $\left(A_{1}>A_{0}, \alpha=\beta=0.10\right)$

$$
E_{A}(T)=\frac{100}{A} \cdot K_{0}
$$

ところで, 上に述べた帰無仮説の㶳却, 採択などの統 計的判断は, 要は検定基準時間数 $X_{0}$ と棄却值 $T_{c}$ との 大小関係を調べていることであるので，もし $T_{c}$ までに $K_{0}$ 件の災害が起こらなければ, 当然 $X_{0}>T_{c}$ となるの で, わざわざ $T_{c}$ 以降 $K_{0}$ 件目の災害が発生する時間 $X_{0}$ まで待って判断を下す必要はない. また， $K_{0}$ 件目の災 害が $T_{c}$ 以前に発生したときは, 当然 $X_{0}$ の時点で判断 を下せばよい。したがって，判断を下すまでの評価時間 数は最大限 $T_{c}$ までを考えればよいこととなる.

ここでは，上述の $T_{c}$ までに $K_{0}$ 件の災害が発生した ときには $X_{0}$ の時点で判断を下し，また， $T_{c}$ までに $K_{0}$ 件の災害がなければ $T_{c}$ で判定する打切方式到による検 定の平均的な評価件数と災害時間について考察を加える こととする.

判定に至るまでの平均的な災害評価件数は, 棄却時間 $T_{c}$ 以前に $K_{0}$ 件の労働災害が発生すれば, その時点 $X_{0}$ で評価を終了するときと， $K_{0}$ 件の災害が $T_{c}$ までに発生 せずに $T_{c}$ で評価を終了するときの 2 つの場合の平均的 な災害数を合計することによって得られ，次式で示され る.

$$
\begin{aligned}
E_{A}(n) & =\sum_{x=0}^{K_{0}} x \cdot P_{r}(X=x \mid A) \\
& =\sum_{x=0}^{K_{0}-1} x \cdot P_{r}(X=x \mid A)+K_{0} \cdot P_{r}\left(X=K_{0} \mid A\right)
\end{aligned}
$$

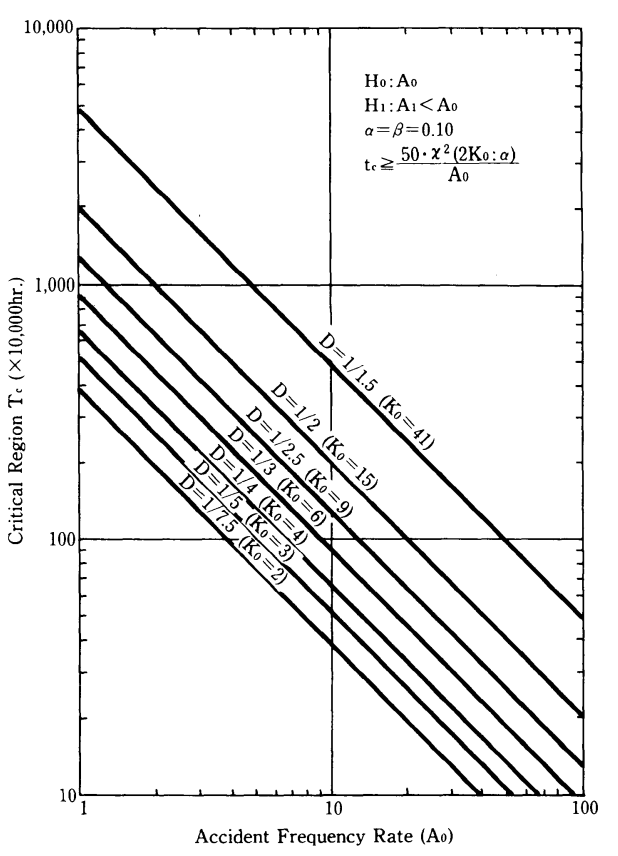

図一2 帰無仮説值 $A_{0}$ と车却域 $T_{c}$ 関係 $\left(A_{1}<A_{0}, \quad \alpha=\beta=0.10\right)$

$$
\begin{aligned}
= & \frac{A}{100} \cdot T_{c}\left[\sum_{x=0}^{K_{0}-2} P\left(x: A \cdot T_{c}\right)\right] \\
& +K_{0} \cdot\left[1-\sum_{x=0}^{K_{0}-1} P\left(x: A \cdot T_{c}\right)\right]
\end{aligned}
$$

ここで,

$$
\begin{aligned}
& P_{r}(X=x \mid A)=P\left(x: A \cdot T_{c}\right) \\
& \quad=\frac{\left(A \cdot T_{c} / 100\right)^{x}}{x !} \cdot \exp \left\{-\left(A \cdot T_{c} / 100\right)\right\}
\end{aligned}
$$

ただし， $A=0$ および $A=\infty$ に対しては, $E_{0}(n)=0$, $E_{\infty}(n)=K_{0}$ である.

また, 平均評価時間数は 1 件当たりの平均発生時間数 が 100/Aであるのでこれを平均災害件数に掛けて，

$$
\begin{aligned}
E_{A}(T)= & E_{A}(n) \cdot 100 / A \\
= & T_{c}\left[\sum_{x=0}^{K_{0}-2} P\left(x: A \cdot T_{\mathrm{c}}\right)\right] \\
& +\frac{100}{A} \cdot K_{0}\left[1-\sum_{x=0}^{K_{0}-1} P\left(x: A \cdot T_{\mathrm{c}}\right)\right]
\end{aligned}
$$

を得る. 同式での， $A=0$ および $A=\infty$ に対する平均評 価時間数はそれぞれ， $E_{0}(T)=T_{c}, E_{\infty}(T)=0$ である.

計算例として, $A>A_{0}$ の検定について平均評価件数 および時間数を求めてみる. 最初に帰無仮説 $H_{0}$ を $A_{0}=$ 5.0 や 10.0 などの適当な值に定め, ついで判別比 $D=$ $A_{1} / A_{0}=2.0$ すなわち, 対立仮説 $H_{1}$ の值が $A_{0}$ の値の 2 倍を想定した検定を考え, 同検定での統計的判断の過誤 $\alpha$ および $\beta$ をともに 0.05 に押さえるものとする.する 
と， $K_{0}=23$ であることが表一 1 から得られ，また， $K_{0}$, $A_{0}$ に対応した棄却域値 $T_{c}$ は式 $(4)$ より，たとえば $A_{0}=5.0$ のときは $T_{c}=314.4$ 万時間として求められる. この $A_{0}, K_{0}, T_{c}$ を用いて式 $(6)$ （ 8 ） よりさまざま な度数率 $A$ に対して平均的な評価件数や平均評価時間 数を求めることができる.

図一3 は上に述べた検定での平均評価件数を求めた結 果を示したものである. 同図より，もし度数率が $A=$ 5.0 であれば， $H_{0}: A_{0}=5.0$ の検定では，平均 16 件目 の災害で仮説が棄却されたり採択されたりすることがわ かる. また，もし度数率が $A \geqq 2 A_{0}$ すなわち帰無仮説 值の 2 倍以上であれば, 䚻無仮説の值 $A_{0}$ にかかわらず 平均評価災害件数は $K_{0}$ に収束することが示されてい る.

また，上記の検定法の平均評価時間数を求めた結果を 図一4に示した。同図には， $A_{0}, K_{0}$ より求められる棄 却域 $T_{c}$ もあわせて破線で示した。同図より, 度数率 $A$

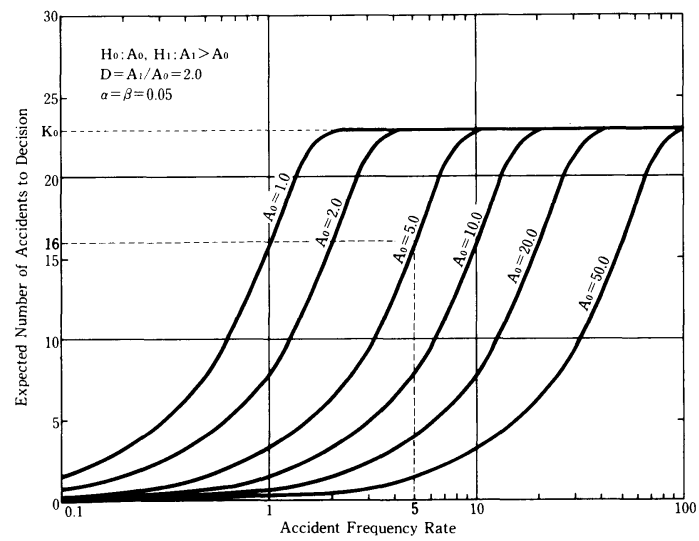

図一3 平均評価災害件数 $\left(A_{1}>A_{0}\right)$

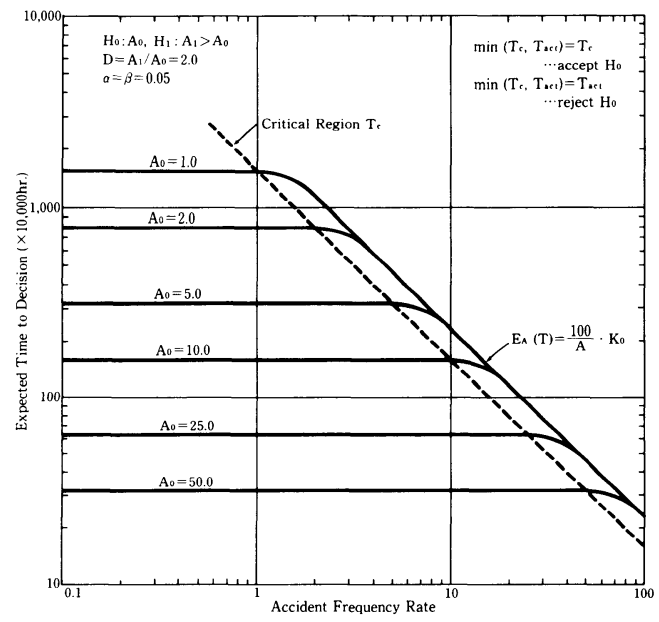

図一4 平均評価時間数 $\left(A_{1}>A_{0}\right)$
が $A \leqq A_{0}$ ，すなわち帰無仮説での值よりも小さければ， 平均評価時間数は $T_{c}$ に収束していることがわかる. 同 じく, 度数率が $A \geqq 2 A_{0}$ つまり帰無仮説值の 2 倍以上 のときの平均評価時間数は, $K_{0}$ 件目の発生時間の平均 時間数である $E_{A}(T)=100 \cdot K_{0} / A$ の包絡線に収束して いることが示されている，いずれの場合でも，平均評価 時間数は $T_{c}$ 以下である.

\section{3. 逐次検定方式による統計的評価 6 (2,9), 10)}

これまで，災害発生時間数を用いて災害度数率の統計 的仮説検定を行う一般的手順亡，そこでの平均的な評価 災害件数や時間数について述べてきた.しかしながら, 前章で考察した検定手順はいわば理想化されたものであ り，すでに述べたとおり，実際にはその場で得られたあ りあわせのデータを用いて評価を実施したり，またはせ ざるを得ないことが多い.

また，これまでの検定法では， $K_{0}$ 件目の災害発生時 間 $X_{0}$ と, 棄却域值 $T_{c}$ との大小関係から評価が行われ ており, $K_{0}-1$ 件までの災害の発生時間数に関する情報 は統計的判断からは捨象された状態となっている.

したがって, より合理的な検定方法としては, 最終判 断に至るまでに要する評価災害件数および評価時間数が できる限り少ないこと, ならびに最終の統計的判断に至 るまでの過程で個々の災害の情報を取り入れたものであ ることが望ましい検定方式であるといえる.

このような要件を充足した検定方法として,ここでは, A. Wald が開発した逐次確率比検定法をとりあげ，同 法による評価を検討することとする。

\section{(1) 逐次検定法の考え方と分析手順 ${ }^{9}$}

逐次検定法の基本的考え方は，検定のための標本の大 きさをあらかじめ指定せずに，得られた標本によって張 られる標本空間を互いに排他な $R_{m}^{0}, R_{m}^{1}, \quad R_{m}(m=$ $1,2, \cdots \cdots)$ の 3 つの領域に分割する方式をとる. そして, 最初の観測值 $x_{1}$ が, $x_{1} \in R_{1}^{0}$ であれば帰無仮説を採択し， $x_{1} \in R_{1}^{1}$ のときは仮説を棄却し, $x_{1} \in R_{1}$ のときは茟却, 採択のどちらの決定もせずに次の観測值まで判定を保留 する. 次のデータが得られて $\left(x_{1}, x_{2}\right) \in R_{2}^{0}$ であれば仮 説を採択し, $\left(x_{1}, x_{2}\right) \in R_{2}^{1}$ のときは仮説を棄却し, $\left(x_{1}\right.$, $\left.x_{2}\right) \in R_{2}$ であれば結論を保留し次のデー夕を観測する. かくして $\left(x_{1}, x_{2}, \cdots \cdots, x_{m}\right) \in R_{m}$ が続く限り観測を行い, $\left(x_{1}, x_{2}, \cdots \cdots, x_{m}\right) \notin R_{m}$ に至って検定を終了する.もし $\left(x_{1}, x_{2}, \cdots \cdots, x_{m}\right) \in R_{m}^{0}$ であれば帰無仮説 $H_{0}$ を採択し, $\left(x_{1}, x_{2}, \cdots \cdots, x_{m}\right) \in R_{m}^{1}$ のときは仮説を棄却する.この ように, データが得られるたびに検定を行うので逐次検 定法よよばれる.

具体的手順としては，まず，パラメーターを $\theta$ とす る母集団確率密度関数を $f(x, \theta)$ とし, 㷌無仮説 $H_{0}$ : 
$\theta=\theta_{0}$ に対して, 対立仮説 $H_{1}: \theta=\theta_{1}$ を検定するものと する. また，母集団からランダムに得られた観測值を $x_{1}$, $x_{2}, \cdots \cdots$ とし, 任意の正数 $m$ に対して, それぞれの仮説 のもとでの結合分布を，

$$
\begin{aligned}
& P_{0 m}=f\left(x_{1}, \theta_{0}\right) \cdot f\left(x_{2}, \theta_{0}\right) \cdots \cdots f\left(x_{m}, \theta_{0}\right) \\
& P_{1 m}=f\left(x_{1}, \theta_{1}\right) \cdot f\left(x_{2}, \theta_{1}\right) \cdots \cdots f\left(x_{m}, \theta_{1}\right)
\end{aligned}
$$

と表わす．このとき $H_{0}$ の $H_{1}$ に対する逐次検定は，あ らかじめ 2 つ正実数 $\boldsymbol{A}, \boldsymbol{B}(\boldsymbol{A}>\boldsymbol{B})$ を定めておき, デー 夕が得られた各段階で尤度比 $P_{1 m} / P_{0 m}$ を計算して, 次 の式の基準に従って検定を行う.

i ) $\boldsymbol{B}<P_{1 m} / P_{0 m}<\boldsymbol{A}$ 判定を保留

ii ) $\quad P_{1 m} / P_{0 m} \geqq A$ 仮説 $H_{0}$ を棄却

iii) $\quad P_{1 m} / P_{0 m} \leqq B$ 仮説 $H_{0}$ を採択

実際の計算では, 尤度比の対数をとり,

$\ln \left(P_{1 m} / P_{0 m}\right)=z_{1}+z_{2}+\cdots \cdots+z_{m}$

ただし，

$$
z_{i}=\ln \frac{f\left(x_{i}, \theta_{1}\right)}{f\left(x_{i}, \theta_{0}\right)} \quad(i=1,2, \cdots, m)
$$

として,

i ) $\ln B<\sum_{i=1}^{m} z_{i}<\ln A \quad$ 判定保留

ii )

$\sum_{i=1}^{m} z_{i} \geqq \ln A \quad H_{0}$ を棄却

iii)

$$
\sum_{i=1}^{m} z_{i} \leqq \ln B \quad H_{0} \text { を採択 }
$$

として評価する方が便利なことが多い。

また, 限界值 $\boldsymbol{A}, \boldsymbol{B}$ は, 第 1 種過誤の確率 $\alpha$, 第 2 種 過誤の確率 $\beta$ なる, 強度 $(\alpha, \beta)$ の検定において近似 的に次式で与えられることが知られている.

$$
\boldsymbol{A}=\frac{1-\beta}{\alpha}, \quad \boldsymbol{B}=\frac{\beta}{1-\alpha}
$$

つまり, 式 (13) で与えられる限界値を用いて式 (9) または（12）に準拠した検定を行えば，そこで生ずる第 1 種と第 2 種の過誤の確率は $\alpha$ および $\beta$ で保証される.

また逐次検定法の特性をより明らかにするための, 同 検定法の作用特性関数 ( OC 関数), および平均標本件 数関数 (ASN 関数) などは以下の手順で示される.

あるパラメーター $\theta$ が真のとき, 䚻無仮説 $H_{0}$ を採択 する確率 $L(\theta)$ をパラメーターの関数とみなして作用 特性関数とよぶのは逐次検定法でも同様である。まず, 任意の $\theta$ に関する関数で, 次式を満足する $h(\theta)(\neq 0)$ を求め,

$E_{\theta}[\exp \{z h(\theta)\}]=1$

得られた $h(\theta)$ を用いて OC 関数が次式で求められる.

$$
L(\theta)=\frac{\boldsymbol{A}^{h(\theta)}-1}{\boldsymbol{A}^{\boldsymbol{h}(\theta)}-\boldsymbol{B}^{\boldsymbol{h}(\theta)}}
$$

また検定が終了するまでの平均的な標本数 $E_{\theta}(n)$ は, 上記の $L(\theta)$ を用いて次式で得られる.

$$
E_{\theta}(n)=\frac{L(\theta) \cdot \ln B+[1-L(\theta)] \cdot \ln \boldsymbol{A}}{E_{\theta}(z)}
$$

ここに,

$$
E_{\theta}(z)=\int_{-\infty}^{\infty}\left[\ln \frac{f\left(x, \theta_{1}\right)}{f\left(x, \theta_{0}\right)}\right] f(x, \theta) d x
$$

また, 1 件のデー夕を得る平均時間を $E_{\theta}(t)$ とすれば, 検定完了までの平均時間数 $E_{\theta}(T)$ を次式で得る.

$E_{\theta}(T)=E_{\theta}(n) \cdot E_{\theta}(t)$

（2）災害発生時間数を用いた逐次検定法による分析 前節での準備をもとに, 災害発生時間数を利用して災 害度数率の変動を逐次検定法で調べる手順を以下に示 す.ただし，仮説検定は帰無仮説 $H_{0}: A=A_{0}$ に対して 対立仮説 $H_{1}: A=A_{1}\left(A_{1}>A_{0}\right.$ or $\left.A_{1}<A_{0}\right)$ で行うものと する. すでに述べたとおり，ある度数率 $A$ のもとでの 発生時間分布の密度関数は指数分布で示され,

$$
f(t \mid A)=(A / 100) \cdot \exp \left\{-\frac{A}{100} t\right\}
$$

したがって，それぞれの仮説のもとでの結合分布は，

$$
\begin{aligned}
P_{1 n} & =f\left(t_{1}, t_{2}, \cdots \cdots, t_{n} \mid A_{1}\right) \\
& =\left(\frac{A_{1}}{100}\right)^{n} \exp \left\{-\frac{A_{1}}{100} \sum_{i=1}^{n} t_{i}\right\} \\
P_{0 n} & =f\left(t_{1}, t_{2}, \cdots \cdots, t_{n} \mid A_{0}\right) \\
& =\left(\frac{A_{0}}{100}\right)^{n} \exp \left\{-\frac{A_{0}}{100} \sum_{i=1}^{n} t_{i}\right\}
\end{aligned}
$$

これらの式より，尤度比は，

$$
\frac{P_{1 n}}{P_{0 n}}=\left(\frac{A_{1}}{A_{0}}\right)^{n} \exp \left\{-\frac{1}{100}\left(A_{1}-A_{0}\right) \sum_{i=1}^{n} t_{i}\right\} \text {. }
$$

よって式 (12) から判定の具体的基準は,

$$
\begin{aligned}
\frac{\beta}{1-\alpha}=\boldsymbol{B} & <\left(\frac{A_{1}}{A_{0}}\right)^{n} \exp \left\{-\frac{1}{100}\left(A_{1}-A_{0}\right) \sum t_{i}\right\} \\
& <\boldsymbol{A}=\frac{1-\beta}{\alpha} \ldots \ldots \ldots \ldots \ldots \ldots \ldots \ldots \ldots \ldots \ldots \ldots \ldots \ldots \ldots \ldots \ldots
\end{aligned}
$$

で示され，同式から，

i ) 対立仮説 $H_{1}: A=A_{1}>A_{0}$ のときは,

$$
\begin{array}{r}
\frac{100\left\{n \cdot \ln \left(A_{1} / A_{0}\right)-\ln A\right\}}{A_{1}-A_{0}}<T \\
<\frac{100\left\{n \cdot \ln \left(A_{1} / A_{0}\right)-\ln B\right\}}{A_{1}-A_{0}}
\end{array}
$$

…次の災害が発生するまで判定を保留する $\frac{100\left\{n \cdot \ln \left(A_{1} / A_{0}\right)-\ln \boldsymbol{A}\right\}}{A_{1}-A_{0}} \geqq T$ 仮説 $H_{0}$ を棄却する

$\frac{100\left\{n \cdot \ln \left(A_{1} / A_{0}\right)-\ln B\right\}}{A_{1}-A_{0}} \leqq T$ 仮説 $H_{0}$ を採択する

ただし， $T=\sum_{i=1}^{n} t_{i}$ である.また， 


$$
\begin{aligned}
& s=\frac{\ln \left(A_{1} / A_{0}\right)}{\left(A_{1}-A_{0}\right) / 100}, \quad h_{0}=\frac{\ln B}{\left(A_{1}-A_{0}\right) / 100} \\
& h_{1}=\frac{\ln A}{\left(A_{1}-A_{0}\right) / 100}
\end{aligned}
$$

とおくと, 式 (21) は,

$$
\begin{aligned}
s n-h_{1}<T & <s n-h_{0} \cdots \cdots \cdot \text { 判定保留 } \\
T & \leqq s n-h_{1} \cdots \cdots \cdot H_{0} \text { を棄却 } \\
T & \geqq s n-h_{0} \cdots \cdots \cdot H_{0} \text { を採択 }
\end{aligned}
$$

となり, $(n, T)$ 平面上で $T=s n-h_{1}, T=s n-h_{0}$ の 2 直線によって 3 分割された領域がそれぞれの判定に 対応していることが示される.

同様に,

ii ）対立仮説 $H_{1}: A=A_{1}<A_{0}$ のときの判定基準は, 式（22）の記号を用いて次式で示される.

$$
\begin{aligned}
s n-h_{0}<T & <s n-h_{1} \cdots \cdots \cdot \text { 判定保留 } \\
T & \geqq s n-h_{1} \cdots \cdots H_{0} \text { を棄却 } \\
T & \leqq s n-h_{0} \cdots \cdots H_{0} \text { を採択 }
\end{aligned}
$$

同式より，前例と同じく $T=s n-h_{1}, T=s n-h_{0}$ の 2 直線によって 3 分割された $(n, T)$ 平面の各領域が, それぞれの判定に対応していることがわかる.

また，上記の逐次検定法における作用特性関数 $L(A)$ は, まず式 $(14)$ を満足する $h(A)$ と $A$ との関係を定 め,

$$
\int_{0}^{\infty}\left[\frac{\lambda_{1} \exp \left\{-\lambda_{1} t\right\}}{\lambda_{0} \exp \left\{-\lambda_{0} t\right\}}\right]^{h(\lambda)} \cdot \lambda \exp \{-\lambda t\} d t=1
$$

ただし， $\lambda=A / 100$ より，

$$
A=\frac{\left(A_{1}-A_{0}\right) \cdot h(A)}{\left(\frac{A_{1}}{A_{0}}\right)^{n(A)}-1}
$$

次に式（15）より，

$$
L(A)=\frac{\left(\frac{1-\beta}{\alpha}\right)^{h(A)}-1}{\left(\frac{1-\beta}{\alpha}\right)^{h(A)}-\left(\frac{\beta}{1-\alpha}\right)^{h(A)}}
$$

によって得られる式（25）および（26）の 2 つの方程式 から $L(A)$ が求められる. すなわち, 式 (25) から $A$ と $h(A)$ との関係を対形式 $(h(A), A)$ で求めておき, その值を式 $(26)$ に代入すれば $(h(A), A)$ に対する $L(A)$ が求められる.さらに式 (17) より,

$$
\begin{aligned}
& E_{\lambda}(z)=\int_{0}^{\infty}\left[\ln \frac{\lambda_{1} \exp \left\{-\lambda_{1} t\right\}}{\lambda_{0} \exp \left\{-\lambda_{0} t\right\}}\right] \lambda \exp \{-\lambda t\} d t \\
& =\ln \left(\frac{\lambda_{1}}{\lambda_{0}}\right)-\frac{\lambda_{1}-\lambda_{0}}{\lambda} \\
& =\ln \left(\frac{A_{1}}{A_{0}}\right)-\frac{A_{1}-A_{0}}{A}
\end{aligned}
$$

となるので, 上で得られた $L(A)$ を用いて，

$$
E_{A}(n)=\frac{L(A) \cdot \ln B+[1-L(A)] \cdot \ln A}{\ln \left(\frac{A_{1}}{A_{0}}\right)-\left(A_{1}-A_{0}\right) / A}
$$

によって，逐次検定法での平均評価災害件数を求めるこ とができる. またこの值を用いてさらに平均評価時間数 が次式で得られる。

$$
E_{A}(T)=\frac{100}{A} \cdot E_{A}(n)
$$

ただし, $A=\left(A_{1}-A_{0}\right) / \ln \left(A_{1} / A_{0}\right)=u$ のときは式 $(28)$ の分母は 0 となり, このとき平均評価件数は,

$$
E_{A=U}(n)=\frac{-\ln A \cdot \ln B}{\left[\ln \left(A_{1} / A_{0}\right)\right]^{2}}
$$

また，そのときの平均評価時間数は次式となる。

$$
E_{A=U}(T)=\frac{-100 \cdot \ln A \cdot \ln B}{\left(A_{1}-A_{0}\right) \cdot \ln \left(A_{1} / A_{0}\right)}
$$

上で述べた逐次仮説検定法の評価関数をより具体的に 示す例として,ここでは， $H_{1}: A_{1}>A_{0}$ の場合について， $H_{0}: A_{0}=5.0, H_{1}: A_{1}=10.0(D=2.0)$ の設定仮説の もとで, 統計的過誤が $\alpha=\beta=0.05$ の水準による逐次検 定を想定し，以下の計算を行った。

まず, $h(A)$ と $A$ との関係は式 $(25)$ から求まり, その結果を図一 5 に示した。 $h(A)$ は $A$ に関して単調 に減少していることがわかる。 ついで，同図に示される $(h(A), A)$ の対形式の結果を用いて式 $(26)$ より,

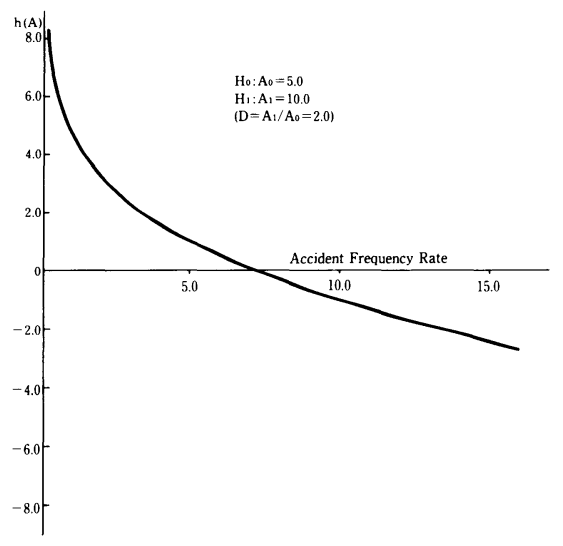

図-5 $h(A)$ と度数率 $A$ との関係 $\left(A_{1}>A_{0}\right)$

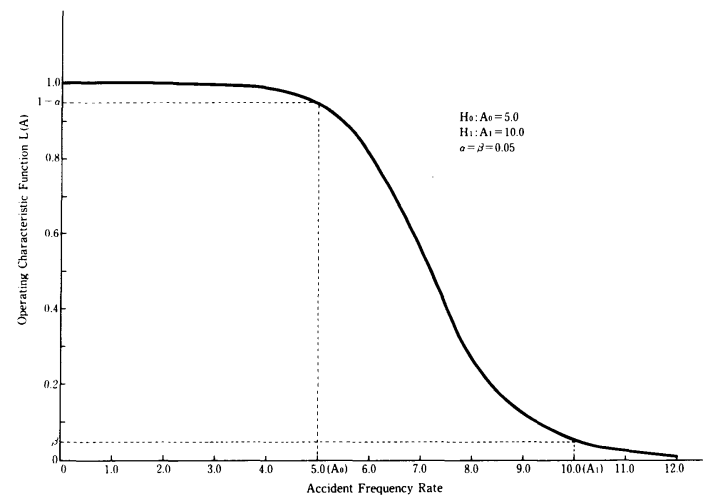

図一6 逐次検定法の作用特性関数 $L(A)\left(A_{1}>A_{0}\right)$ 
当該逐次検定法の作用特性関数（OC 曲線）を求めると 図一 6 となる. 同図より，災害度数率が $A=5.0$ のとき の $L(A)$ は, 帰無仮説值 $A_{0}$ のもとで $H_{0}$ を採択する確 率 1- $\alpha=0.95$ に等しく, また $A=10.0$ のときは対立仮 説值のもとで帰無仮説が採択される確率 $\beta=0.05$ に等 しいことが容易にみてとれる.

さらに，この $L(A)$ を利用して式 $(28)$ より平均評 価災害件数が求められ, その結果を図一7に示した。同 図には，前節で調べた式（6）による打切り方式のとき の平均評価災害件数を比較のために付け加えておいた.

同図より, 度数率がいかなる値であっても, 逐次検定法 による平均評価災害件数は, 前節の打切り方式による検 定の評価件数よりも少ないことが示されている.たとえ ば, $A=5.0$ のときの平均件数は打切り方式では 16 件 であるが，逐次検定法では約 8.6 件ほどである．また， 打切り方式では $A \geqq 2 A_{0}$ の領域では $K_{0}$ に収束している のに対して (図一3), 逐次検定方式では $A$ が $h(A)=0$ となる $\left(A_{1}-A_{0}\right) / \ln \left(A_{1} / A_{0}\right)$ 近傍で極值をもったのち 急激に減少していることが示されている.この性質は, 度数率が $A_{1}>A_{0}$ であることを予想して対立仮説を設定

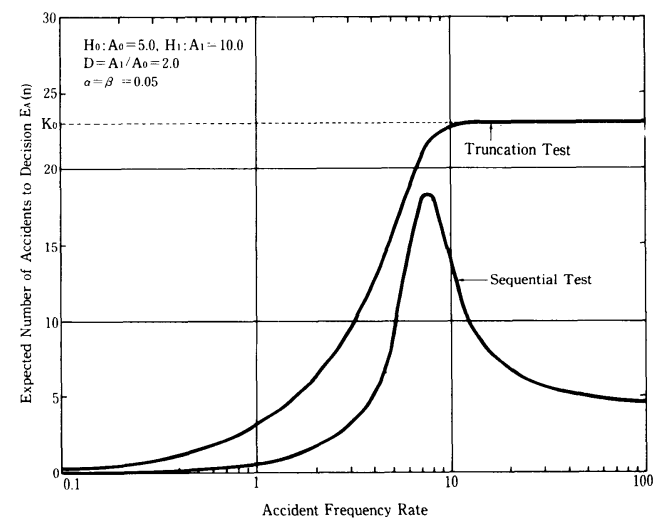

図一7 平均評価災害件数 $\left(A_{1}>A_{0}\right)$

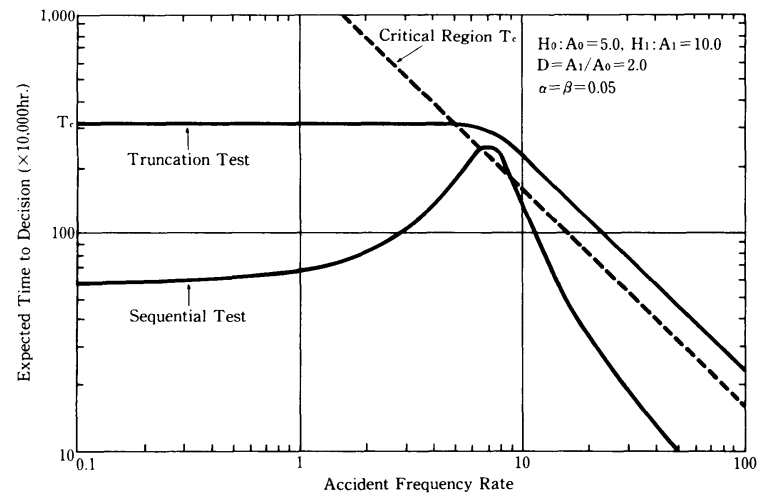

図一8 平均評価時間数 $\left(A_{1}>A_{0}\right)$
する検定では, 評価件数を少なくするうえで効果的な特 性であると思われる.

またこの図からさらに，逐次検定が終了するまでの平 均的な評価時間数を求めることができ，その結果を図一 8 に示した．同図には，打切り方式による平均評価時間 数とともに, $K_{0}$ 件目の棄却域（図中の破線）もあわせ て記した，同図より，平均評価件数と同様に，すべての $A$ に対して逐次検定法による平均評価時間数は打切り 方式によるそれよりも少ないことが示されている.たと えば, 度数率が対立仮説值 $A=10.0$ に等しいとき, 打 切り方式では 228.7 万時間であるのに対し, 逐次検定方 式での平均評価時間数は 137.2 万時間と, ちょうど 40\% ほど改善されていることがわかる. また，打切り 方式では, $A \leqq A_{0}$ の領域にあっては $K_{0}$ 件目の棄却域値 $T_{c}$ に平均評価時間数は収束しているが, 逐次検定方式 では $A \leqq A_{0}$ であっても評価時間数が減少していること が特徴として挙げられる.

\section{（3） 実例による分析 ${ }^{5)}$}

本節では，これまで述べてきた逐次検定法を，実際に 発生した労働災害に適用して労働災害発生率が変動する 様子を分析した結果を以下に述べることとする.

分析に用いた労働災害のデータは, 昭和 56 年から 59 年までの 4 年間に日本国内で発生した重大災害 (一度に 3 人以上の負傷者を含んだ災害) である.この重大災害 の発生時刻は, 実労働時間数ではなく年・月・日の形式 で記録されているので, 単位時間当たりの災害発生数で ある災害発生率として, 延労働時間数当たりの災害発生 数である災害度数率を求めることはできなかった。そこ で，ここでは，1 週間当たりの災害発生数を災害発生率 と定義し, 同災害発生率の変動を発生時間数（同じく週 を 1 単位として計測した）を用いて逐次検定法による分 析を試みることとした。

分析の手順としては，まず，重大災害を業種別あるい は災害の種類別などに分類したのち，各区分の災害を発 生年月日に従って前期 (昭和 56, 57 年) と後期 (昭和 58, 59 年) との 2 グループに区分した. ついで，それぞれ の災害区分ごとに，前期における 1 週間当たりの平均災 害発生率を計算し，この前期の災害発生率を仮説検定に おける帰無仮説值に用いることとした。この帰無仮説値 に対して, いくつかの対立仮説を設定したのち, 後期の 災害デー夕を用いて逐次検定法により災害発生率変動の 評価を行った．検定の過程でもし仮説の棄却あるいは採 択がなされず保留が続き，災害件数が前章で述べた $K_{0}$ 件に達したときは, その時点で通常の検定法で判断を下 すこととした。

図一9は，建設工事において発生した土砂崩壊による 重大災害を逐次検定法で分析した結果を図示したもので 
ある. 同図では, 前期 2 年間の平均災害発生率 0.21 件 /週を帰無仮説の值とし，対立仮説值を帰無仮説の 2 倍 0.42 件／週（判別比 $D=2.0 ）$ と設定し， $\alpha$ および $\beta$ を それぞれ 0.05 としたときの分析結果である. $D=2.0$,

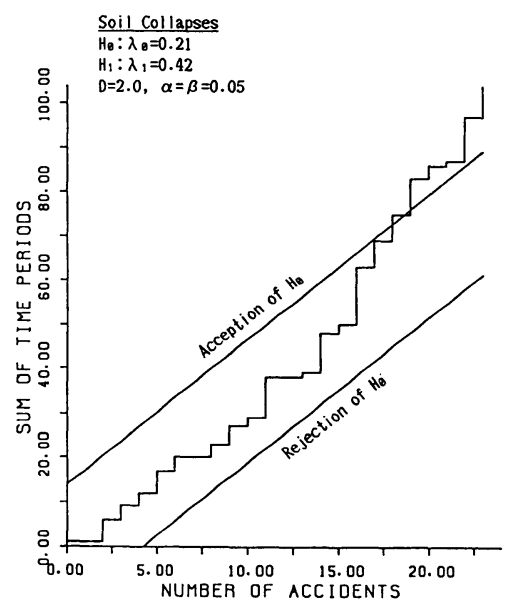

図一9 逐次検定法による土砂崩壊災害の分析（1

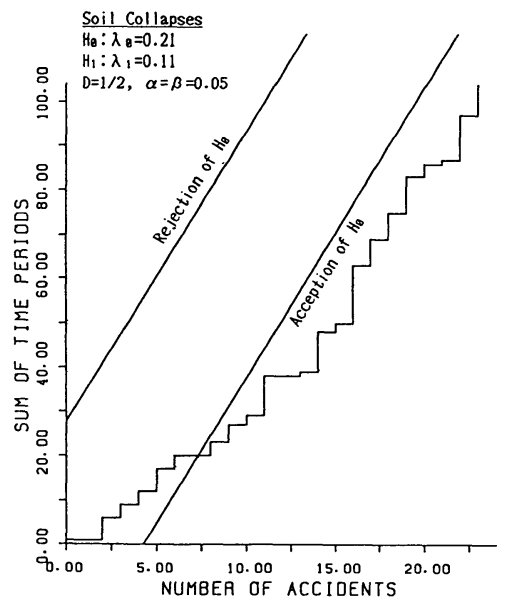

図一10 逐次検定法による土砂崩壊災害の分析（2） $\alpha=\beta=0.05$ の検定に対する最小必要災害件数は表一1 より $K_{0}=23$ で与えられるが, 同図からは災害件数が 19 件目に帰無仮説 $H_{0}$ が採択されており, 災害頻度率が 2 倍ほどには大きくなっていないことが示されている.

同様に図一10は，同じ土砂崩壊重大災害を，対立仮 説値を帰無仮説の半分の 0.11 件 $/$ 週 $(D=1 / 2)$ とした ときの逐次検定法による分析結果である，第 1 種過誤お よび第 2 種過誤はともに図一 9 と同じく $\alpha=\beta=0.05$ で ある. この検定水準に対する最小必要災害件数は表一2 より $K_{0}=23$ であるが，同図からは 8 件目で同じく帰無 仮説が採択されており, 後期の災害発生率が前期の $1 / 2$ ほどには小さくなっていないことが示されている。

以上の分析結果から，土砂崩壊による重大災害の発生 率は, 結局, 前期, 後期の 4 年間を通じて目立った変化 はみられないといえる. 同じ結論を通常の仮説検定で得 るには $K_{0}=23$ 件で判定せねばならず，逐次検定法では より少ない災害数で評価できることが示されている.

また表一3は，災害の種類別に分類した重大災害を， このような手順で逐次検定法によって分析した結果をま とめて示したものである．同表には，前期における災害 発生数, 週を単位とした平均発生率 $\left(\lambda_{0}\right)$, 後期に発生 した災害数を記したのち, 帰無仮説を $H_{0}: \lambda=\lambda_{0}$ と設定 して, Test ( 1$)\left(\lambda>\lambda_{0}\right)$ では, $H_{1}: \lambda=1.50 \lambda_{0}$ と $\lambda=$ $2.0 \lambda_{0}$ の 2 種類の対立仮説での逐次検定の結果を, また, Test ( 2$)\left(\lambda<\lambda_{0}\right)$ では, $H_{1}: \lambda=0.67 \lambda_{0}$ と $\lambda=0.50 \lambda_{0}$ の 2 通りの対立仮説について逐次検定を行った結果を, そして最後に，これらの逐次検定による分析結果を総合 的に考慮した判定結果をそれぞれ順に記した.

同表に示された結果より，増加していると判断された 災害の種類は, 可燃性ガスによる爆発災害や, 墜落によ る災害なよ゙であり,一方, 減少がみられた災害は, クレー ン・デリック等に起因した災害や，倒壊や火災等による 災害などであることがわかる。

また産業別に分析した結果（表略）からは，最近の産 業構造の変化を反映して, 商業などの第 3 次産業の災害

表一3 炎害種類別逐次確率比検定分析結果（昭和 56,57 年 vs 58,59 年)

\begin{tabular}{|c|c|c|c|c|c|c|c|c|}
\hline \multirow{2}{*}{ 災害の種類 } & \multirow{2}{*}{$\begin{array}{l}\text { 前 期 } \\
\text { 災害数 }\end{array}$} & \multirow{2}{*}{$\begin{array}{l}\text { 災害率: } \lambda \text { 日 } \\
(\text { 件 } / \text { 週) }\end{array}$} & \multirow{2}{*}{$\begin{array}{l}\text { 後 期 } \\
\text { 災害数 }\end{array}$} & \multicolumn{2}{|c|}{ Test (1); $H \theta=\lambda \theta$} & \multicolumn{2}{|c|}{ Test (2) : $H_{\theta}=\lambda \theta$} & \multirow{2}{*}{ 全体評価 } \\
\hline & & & & $H_{1}=1.5 \lambda_{0}$ & $H_{1}=2.0 \lambda_{\theta}$ & $H_{1}=2 / 3 \lambda_{0}$ & $H_{1}=1 / 2 \lambda_{B}$ & \\
\hline ガス爆発 & 13 & 0.125 & 22 & 棄却 & 棄却 & 採択 & 採択 & 非常に増 \\
\hline 土砂崩壊 & 22 & 0.212 & 23 & 保留 & 採択 & 採択 & 採択 & 不変 \\
\hline 倒 壊 & 28 & 0.269 & 20 & 採択 & 採択 & 保留 & 保留 & やや減 \\
\hline 陮 落 & 17 & 0.163 & 25 & 保留 & 裹却 & 採択 & 採択 & かなり增 \\
\hline 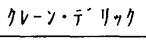 & 21 & 0.202 & 6 & 採択 & 採択 & 棄却 & 裹却 & 非常に減 \\
\hline 交通事故 & 162 & 1.558 & 165 & 採択 & 採択 & 採択 & 採択 & 不変 \\
\hline 火災 & 34 & 0.327 & 24 & 採択 & 採択 & 保留 & 保留 & やや減 \\
\hline その他 & 14 & 0.135 & 28 & 衰却 & 棄却 & 採択 & 採択 & 非常に增 \\
\hline
\end{tabular}


発生率が増加している一方で, 貨物取扱業の災害が減少 していることが示されたほか，建設工事における災害は 全体として大きな変化がないことが明らかにされた。

このように, 逐次検定法では数少ない災害数の発生時 間数をよりどころとして, 災害発生率の変動を統計的に 評価し判断を下すことが可能であり，また仮に 1 つの検 定で最終判断に達することができなくとも，図一9，10， あるいは表一3に示したように，いくつかの検定を組み 合わせることにより，全体の災害動向を調べることがで きる.

また，そのほかにも逐次検定法は，検定の各段階にお ける炎害発生状況を（発生件数-発生時間累計曲線）図 の平面上で視覚的に把握できる利点を有しており，事業 所で行う安全性評価のための災害管理図として同図は有 効に利用できると思われる.

\section{4. まと め}

以上, 本論文では, 事業所における労働安全性の水準 を評価する方法として，労働災害が発生するまでの時間 数を用いて, 災害発生率が変動する過程を分析する手法 について，特に少数の災害データで評価を行うことが可 能な逐次検定法に力点をおいて考察を加えたのち，実際 に発生した災害の分析を試みた。本論文で検討した内容 の主な点を記すと，

（1）労働災害が発生する時間数の分布を，事業所で の安全性評価指標として広く用いられている災害度数率 と関連づけて記述することにより，ある度数率のもとで の災害発生時間数を確率的に評価できることを示した。

（2）労働災害発生時間数を用いて安全性評価を行う ための仮説検定法の評価手順を示し，あわせて，統計的 過誤を所定水準内で充足させるための必要評価件数や， 仮説検定の評価関数である, 平均評価災害件数や平均評 価時間数などについて検討を加えた。

（3）通常の仮説検定と同等の統計的過誤を保証し， かつ評価に要する災害件数が少なく, 評価時間数も短く 済ませることができる逐次検定法を取り上げ，同手法を 用いて災害発生率の変動を評価する手順を示すととも に，平均評価災害件数や平均評価時間数などを求めた。

（4）事例分析として重大災害を取り上げ，災害種類 別などに分類して災害動向の分析評価を行い，建設工事 全体としては災害動向に大きな変化がみられないこと や, 災害の種類別では, 墜落災害が増えていることなど, いくつかの特徴を見出すことができた。

（5）逐次検定法は，災害が起こるたびに検定を行う ので，検定の経過を図示化した（災害発生件数-累計災 害発生時間数）図は，事業所での災害管理図としても利
用できることを示した。

\section{5. あとがき}

本論文で扱った労働災害が発生するまでの時間数（災 害発生時間数）は，労働災害に関するさまざまな情報の 中でも比較的入手しやすい情報であることや，また，災 害発生時間数を利用した評価内容も，たとえば，本研究 で示した，災害発生率の仮説検定（逐次検定も含む）に よって災害危険性の変動を検出できることなど，事業所 において労働安全性評価を行うのに適した便利な尺度で あると考えられる.

また，災害発生時間数による評価法は，これを実際に 行われているさまざまな安全管理手法と関連させること によって，安全管理法の効果を早く測定することも期待 でき，今後の有効な安全管理手法開発を支援する手段と しての応用も考えられる. 今後はこの方面の研究も進め たいと考えている.

最後に，本研究を進めるにあたり，北海道大学工学部 菅原照雄教授，佐伯 浩教授，佐藤馨一助教授加ら有益 なるご助言を頂きました．また災害資料の利用には，労 働省労働基準局安全課のご協力を頂きました。ここに厚 く感謝の意を表する次第です。

\section{参 考 文 献}

1）たとえば，労働災害動向調查報告（昭和 62 年版），労働 大臣官房政策調查部，1988.

2）花安繁郎：災害発生間隔の分布に関する研究，労働省産 業安全研究所研究報告, RIIS-RR-26-3，1977

3）花安繁郎：災害発生時間による安全水準の評価について, 土木学会論文報告集，第 301 号，pp. 105 113， 1980.

4）花安繁郎：災害発生時間の分布に関する研究（2), 労働 省産業安全研究所研究報告, RIIS-RR-32-4, 1984.

5）花安繁郎：労働災害発生系列の均質性に関する研究，建 築学会構造系論文報告集，第 352 号，pp. 1 9， 1985.

6）花安繁郎：災害発生時間の分布に関する研究（3), 労働 省産業安全研究所研究報告, RIIS-RR-86-6, pp. 69 - 92, 1987.

7）近藤良夫・舟阪 渡 編著：技術者のための統計的方法, 共立出版，pp. 82 89，1973.

8) Epstein, B. : Truncated Life Tests in the Exponential Case, Annals of Mathematical Statistics, Vol. 25, pp. 555 564, 1954.

9) Wald, A. : Sequential Analysis, John Wiley \& Sons, 1947.

10) Epstein, B. and Sobel, M. : Sequential Life Test in the Exponential Case, Annals of Mathematical Statistics, Vol. 26, pp. 82 93, 1955.

(1989.2.2 • 受付) 